\title{
MYB promotes the growth and metastasis of salivary adenoid cystic carcinoma
}

\author{
LI-HUA XU ${ }^{1}$, FEI ZHAO ${ }^{1}$, WEN-WEN YANG ${ }^{1}$, CHU-WEN CHEN $^{1}$, \\ ZHI-HAO DU ${ }^{1}$, MIN FU ${ }^{1}$, XI-YUAN GE ${ }^{1,2}$ and SHENG-LIN LI ${ }^{1,2}$ \\ ${ }^{1}$ Central Laboratory, Peking University School and Hospital of Stomatology, National Clinical Research Center \\ for Oral Diseases, National Engineering Laboratory for Digital and Material Technology of Stomatology, \\ Beijing Key Laboratory of Digital Stomatology; ${ }^{2}$ Department of Oral and Maxillofacial Surgery, \\ Peking University School and Hospital of Stomatology, Beijing 10081, P.R. China
}

Received July 6, 2018; Accepted February 4, 2019

DOI: $10.3892 /$ ijo.2019.4754

\begin{abstract}
The incidence of recurrent $\mathrm{t}(6 ; 9)$ translocation of the $M Y B$ proto-oncogene to NFIB (the gene that encodes nuclear factor 1 B-type) in adenoid cystic carcinoma (ACC) tumour tissues is high. However, $M Y B$ [the gene that encodes transcriptional activator Myb (MYB)] overexpression is more common, indicating that MYB serves a key role in ACC. The current study aimed to investigate the role of MYB in salivary (S)ACC growth and metastasis. A total of 50 fresh-frozen SACC tissues and 41 fresh-frozen normal submandibular gland (SMG) tissues were collected to measure $M Y B$ mRNA expression, and to analyse the associations between $M Y B$ and epithelial-mesenchymal transition (EMT) markers. Compared with normal SMG tissue, SACC tissues demonstrated significantly increased $M Y B$ expression, with a high expression rate of $90 \%$. Interestingly, $M Y B$ tended to be negatively correlated with $C D H 1$ [the gene that encodes cadherin-1 (E-cadherin)] and positively correlated with VIM (the gene that encodes vimentin), suggesting that MYB is associated with SACC metastasis. To explore the role of MYB in SACC,
\end{abstract}

Correspondence to: Dr Xi-Yuan Ge or Professor Sheng-Lin Li, Central Laboratory, Peking University School and Hospital of Stomatology, National Clinical Research Center for Oral Diseases, National Engineering Laboratory for Digital and Material Technology of Stomatology, Beijing Key Laboratory of Digital Stomatology, 22 South Zhongguancun Avenue, Beijing 100081, P.R. China

E-mail: gexiyuan@bjmu.edu.cn

E-mail: kqshlli@bjmu.edu.cn

Abbreviations: MYB, transcriptional activator Myb; $C C N D 1$, the gene encoding G1/S-specific cyclin-D1; ACC, adenoid cystic carcinoma; EMT, epithelial-mesenchymal transition; SMG, submandibular gland; p21, the gene encoding cyclin-dependent kinase inhibitor 1; ICAM1, the gene encoding intercellular adhesion molecule 1; VEGF, vascular endothelial growth factor A

Key words: adenoid cystic carcinoma, transcriptional activator Myb, lung metastasis, epithelial-mesenchymal transition the authors stably overexpressed and knocked down $M Y B$ in SACC cells. The authors of the current study demonstrated that $M Y B$ overexpression promoted SACC cell proliferation, migration and invasion, whereas its knockdown inhibited these activities. Additionally, when $M Y B$ was overexpressed, $C D H 1$ expression was downregulated, and $\mathrm{CDH} 2$ (the gene that encodes cadherin-2), VIM and ACTA2 (the gene that encodes actin, aortic smooth muscle) expression was upregulated. Then, the effect of $M Y B$ on lung tumour metastasis was investigated in vivo in non-obese diabetic/severe combined immunodeficiency mice. $M Y B$ overexpressing and control cells were injected into the mice through the tail vein. The results revealed that MYB promoted SACC lung metastasis. Collectively, these results demonstrated that $M Y B$ is aberrantly overexpressed in SACC tissues, and promotes SACC cell proliferation and metastasis, indicating that MYB may be a novel therapeutic target for SACC.

\section{Introduction}

Salivary adenoid cystic carcinoma (SACC) is one of the most common malignancies of the salivary glands and is characterized by slow indolent growth, frequent local recurrences, a high incidence of metastasis and a poor prognosis (1-3). A total of 40-60\% of patients with SACC suffer distant metastasis even when treated with surgical resection and intensive radiotherapy $(4,5)$. The lung is the most common distant metastasis site, followed by bone, liver and brain (6). However, no effective treatment is available to inhibit or reduce lung metastases (6-8). Thus, there is an urgent need to find novel treatments to suppress SACC tumour metastasis, especially lung metastases.

$M Y B$ [the gene that encodes transcriptional activator Myb (MYB)]-NFIB (the gene that encodes nuclear factor 1 B-type) fusion occurred in 119/232 (51\%) of SACCs, and MYB mRNA overexpression was detected in 119/136 (88\%) of SACCs (9-15), indicating that MYB may serve an important role in the occurrence and development of SACC. MYB is associated with the development of tumours, including leukaemia, pancreatic cancer, breast cancer and prostate cancer (16-18). However, whether MYB is associated with the development and metastasis of SACC is not clear (19). 
Epithelial-mesenchymal transition (EMT) is a typical event in SACC metastasis $(20,21)$. Changes in cellular morphology and phenotypic characteristics facilitate epithelial cell transformation into cells with mesenchymal features, which gain an invasive phenotype and stronger motility (22-24). During EMT, the expression of cell adhesion molecules, such as cadherin-1 (E-cadherin, encoded by $C D H 1$ ), decrease, and the expression of mesenchymal markers, including vimentin (encoded by VIM) and cadherin-2 (N-cadherin, encoded by $\mathrm{CDH} 2$ ), increase (25). MYB has been reported to enhance breast cancer metastasis by activating the Wnt/catenin $\beta-1$ ( $\beta$-catenin)/Axin-2 signalling pathway, which is one of the most important pathways that leads to EMT activation. However, whether MYB is associated with EMT during SACC metastasis is unclear. Based on the aforementioned studies, the authors of the current study aimed to explore the effect of MYB on the development and lung metastasis of SACC, and to analyse the association of MYB and EMT with SACC metastasis.

\section{Materials and methods}

Human tissue samples. A total of 10 human SACC tissues and 10 paired normal submandibular gland (SMG) tissues were used for the microarray analysis. They were collected from patients with SACC at the Peking University School and Hospital of Stomatology (Beijing, China) between August 2015 and April 2016. A total of 50 human SACC and 41 SMG tissues collected between June 2008 and September 2013 at the Peking University School and Hospital of Stomatology were also used to analyse $M Y B$ expression in tissues. Patients had not undergone radiation therapy or chemotherapy. The tumours were classified according to the histological classification of salivary gland tumours proposed by the World Health Organization (26). The clinicopathological data are summarized in Table I. The study was approved by the Ethics Committee of Peking University School and Hospital of Stomatology (permit no. PKUSSIRB-201522040).

Microarray gene expression analysis. Total RNA was extracted from the 10 human SACC and 10 paired SMG tissues using TRIzol (Invitrogen; Thermo Fisher Scientific, Inc., Waltham, MA, USA) following the manufacturer's protocol. Then the RNA was purified using the RNeasy Midi kit (Qiagen Sciences, Inc., Gaithersburg, MD, USA). Hybridization was performed by Shanghai Biotechnology Corporation (Shanghai, China) using The Shbio Human ceRNA microarray v1.0 (for mRNA/circular RNA/long non-coding RNA detection) and the SurePrint Human miRNA microarray v21.0 (Agilent Technologies, Inc., Santa Clara, CA, USA), which contained 18,853 mRNA probes per array product. Genes with fold changes $>2$ and $\mathrm{P}<0.05$ were identified as differentially expressed genes, of which 15 were identified.

Reverse transcription-quantitative polymerase chain reaction (RT-qPCR) analysis. Total RNA was isolated from tissues or cells with the TRIzol reagent (Invitrogen; Thermo Fisher Scientific, Inc.) according to the manufacturer's protocol. The PrimeScript $^{\mathrm{TM}}$ RT kit (cat.no.DRR037A; Takara Biotechnology Co., Ltd., Dalian, China) was used to synthesize the cDNA using $1 \mu \mathrm{g}$ total RNA, according to the manufacturer's protocol.
All primer sequences (sense/antisense) were as follows: MYB:5'-GCCAATTATCTCCCGAATCGA-3'/5'-ACCAACGT TTCGGACCGTA-3'; CDH1: 5'-GACCGGTGCAATCTTC AAA-3'/5'-TTGACGCCGAGAGCTACAC-3'; vimentin: 5'-GACGCCATCAACACCGAGTT-3'/5'-CTTTGTCGTTGG TTAGCTGGT-3'; G1/S-specific cyclin-D1 (encoded by $C C N D 1):$ 5'-GATCAAGTGTGACCCGGACT-3'/5'-TCC TCСТCTТССТССТССТC-3'; cyclin-dependent kinase inhibitor 1 (encoded by p21): 5'-TGCCCAAGCTCTACCT TCC-3'/5'-CAGGTCCACATG GTCTTCCT-3'; induced myeloid leukemia cell differentiation protein $\mathrm{Mcl}-1$ (encoded by $M C L 1$ ):5'-TGCATCGAACCATTAGCAGA-3'/5'-TCCTGATG CCACCTTCTAGG-3'; intercellular adhesion molecule 1 (encoded by ICAM1): 5'-CACAGTCACCTATGGCA ACG-3'/5'-GTGTCTCCTGGCTCTGGTTC-3'; vascular endothelial growth factor A (VEGF, encoded by VEGFA): 5'-CTT GCCTTGCTGCTCTACCT-3'/5'-AGCTGCGCTGATAGACA TCC-3'; matrix metalloproteinase-7 (MMP-7, encoded by MMP7): 5'-GTCTCGGAGGAGATGCTCAC-3'/5'-GGAATG TCCCATACCCAAAG-3'; MMP9: 5'-GCCTGGCACATAG TAGGCCC-3'/5'-CTTCCTAGCCAGCCGGCATC-3'; and GAPDH: 5'-CCATGGAGAAGGCTGGG-3'/5'-CAAAGTTG TCATGGATGACC-3'. Quantification of mRNA expression was performed with the FastStart Universal SYBR Green Master (ROX) reagent (Roche Diagnostics, Basel, Switzerland) using the ABI 7500 Sequence Detection System (Thermo Fisher Scientific, Inc.). The amplification conditions were as follows: $50^{\circ} \mathrm{C}$ for $2 \mathrm{~min}, 95^{\circ} \mathrm{C}$ for $10 \mathrm{~min}$, and 40 cycles at $95^{\circ} \mathrm{C}$ for $15 \mathrm{sec}$ and $60^{\circ} \mathrm{C}$ for $1 \mathrm{~min}$, followed by a dissociation curve stage to check amplification specificity. The mRNA expression levels of the target genes were normalized to GAPDH and calculated using the $\Delta \mathrm{CT}$ and $\Delta \Delta \mathrm{CT}$ methods (27).

Cell lines and transfection. The SACC- 83 cell line originated from the ACC tissue of a 26-year-old female patient's sublingual gland in November 1983 (28). The SACC-LM cell line exhibited enhanced lung metastatic behaviour and were isolated in vivo after injecting SACC- 83 cells into the tail veins of immunodeficient mice (21-23). The SACC-83 and SACC-LM cell lines were collected by SLL and kept at Peking University School and Hospital of Stomatology. The pSMG cells were derived from a 4-year-old boy patient's sublingual gland in November 2016 (29). The pSMG cell line was collected by ZHD and kept at Peking University School and Hospital of Stomatology. SACC-83 and SACC-LM cells were maintained in RPMI-1640 medium supplemented with $10 \%$ fetal bovine serum (FBS; both Gibco; Thermo Fisher Scientific, Inc.) at $37^{\circ} \mathrm{C}$ in a humidified atmosphere containing $5 \% \mathrm{CO}_{2}$. The pSMG cells were cultured with DMEM/F12 (1:1 mixture; Gibco; Thermo Fisher Scientific, Inc.) containing $2.5 \% \mathrm{FBS}$, trace element mix (Gibco; Thermo Fisher Scientific, Inc.), $20 \mathrm{nM}$ sodium selenite, $5 \mu \mathrm{g} / \mathrm{ml}$ transferrin (Gibco; Thermo Fisher Scientific, Inc.), $1.1 \mu \mathrm{M}$ hydrocortisone, $0.1 \mu \mathrm{M}$ retinoic acid, $2.0 \mathrm{nM} \mathrm{T}$, $8.4 \mathrm{ng} / \mathrm{ml}$ cholera toxin (Sigma-Aldrich; Merck KGaA, Darmstadt, Germany), $5 \mu \mathrm{g} / \mathrm{ml}$ insulin, $80 \mathrm{ng} / \mathrm{ml}$ epidermal growth factor (both Gibco; Thermo Fisher Scientific, Inc.), extra glutamine (final concentration, $5 \mathrm{mM}$ ), $50 \mu \mathrm{g} / \mathrm{ml}$ gentamicin sulfate and $1 \mu \mathrm{g} / \mathrm{ml}$ amphotericin B (Gibco; Thermo Fisher Scientific, Inc.). 
Table I. Correlation between clinicopathological variables and MYB expression in patients with salivary adenoid cystic carcinoma.

\begin{tabular}{|c|c|c|c|c|c|}
\hline \multirow[b]{2}{*}{$\begin{array}{l}\text { Variables } \\
\text { (n) }\end{array}$} & \multirow[b]{2}{*}{$\begin{array}{l}\text { Total } \\
\text { (n) }\end{array}$} & \multicolumn{2}{|c|}{ MYB expression } & \multirow[b]{2}{*}{$\chi^{2}$} & \multirow[b]{2}{*}{ P-value } \\
\hline & & $\begin{array}{l}\text { Low } \\
\text { (n) }\end{array}$ & High & & \\
\hline Age (years) & & & & 0.786 & 0.375 \\
\hline$<42$ & 18 & 6 & 12 & & \\
\hline$\geq 42$ & 32 & 7 & 25 & & \\
\hline Sex & & & & 1.708 & 0.191 \\
\hline Male & 23 & 8 & 15 & & \\
\hline Female & 27 & 5 & 22 & & \\
\hline Tumour size & & & & 3.814 & 0.051 \\
\hline$<4 \mathrm{~cm}$ & 31 & 11 & 20 & & \\
\hline$\geq 4 \mathrm{~cm}$ & 19 & 2 & 17 & & \\
\hline Clinical stage & & & & 4.372 & 0.037 \\
\hline $\mathrm{I} / \mathrm{II}$ & 26 & 10 & 16 & & \\
\hline I II/IV & 24 & 3 & 21 & & \\
\hline Site & & & & 1.418 & 0.234 \\
\hline $\begin{array}{l}\text { Major salivary } \\
\text { gland }\end{array}$ & 13 & 5 & 8 & & \\
\hline $\begin{array}{l}\text { Minor salivary } \\
\text { gland }\end{array}$ & 37 & 8 & 29 & & \\
\hline Pathological type & & & & 7.031 & 0.030 \\
\hline Cribriform & 13 & 6 & 7 & & \\
\hline Tubular & 25 & 7 & 18 & & \\
\hline Solid & 12 & 0 & 12 & & \\
\hline $\begin{array}{l}\text { Lymph node } \\
\text { metastasis }\end{array}$ & & & & 0.191 & 0.662 \\
\hline Absent & 44 & 11 & 33 & & \\
\hline Present & 6 & 2 & 4 & & \\
\hline $\begin{array}{l}\text { Perineural } \\
\text { invasion }\end{array}$ & & & & 0.082 & 0.775 \\
\hline Absent & 17 & 4 & 13 & & \\
\hline Present & 33 & 9 & 24 & & \\
\hline $\begin{array}{l}\text { Lung } \\
\text { metastasis }\end{array}$ & & & & 5.418 & 0.020 \\
\hline Absent & 33 & 12 & 21 & & \\
\hline Present & 17 & 1 & 16 & & \\
\hline $\begin{array}{l}\text { Local regional } \\
\text { recurrence }\end{array}$ & & & & 0.090 & 0.764 \\
\hline Absent & 21 & 5 & 16 & & \\
\hline Present & 29 & 8 & 21 & & \\
\hline
\end{tabular}

$M Y B$, the gene that encodes transcriptional activator Myb.

The lentiviral vector pHBLV-CMV-GFP-T2A-puro, empty (negative control) lentiviral vector and auxiliary transfection reagent, Polybrene, were purchased from Shanghai GenePharma Co., Ltd. (Shanghai, China). The $M Y B$ overexpressing lentiviral vector or empty lentiviral vector with a virus titre of $1 \times 10^{8} \mathrm{TU} / \mathrm{ml}$ were transfected into SACC- 83 cells. The multiplicity of infection was 50 . After $72 \mathrm{~h}$ of transfection, SACC-83 cells were incubated in RPMI-1640 medium containing $3 \mu \mathrm{g} / \mathrm{ml}$ puromycin for $72 \mathrm{~h}$ to select cells that had been successfully transfected, and then the cells were cultured in RPMI-1640 medium containing $1.5 \mu \mathrm{g} / \mathrm{ml}$ puromycin for 2 weeks to obtain $M Y B$ overexpressing (MYB OE) or negative control (NC) SACC-83 cells. The GFP-positive cells were sorted using BD FACS Aria II (BD Bioscience, San Jose, CA, USA) and cultured in RPMI-1640 medium supplemented with $10 \% \mathrm{FBS}$ at $37^{\circ} \mathrm{C}$ in a humidified atmosphere containing $5 \% \mathrm{CO}_{2}$. Monoclonal cell lines that stably overexpressed $M Y B$ (M1, M2 and M3 cells) and monoclonal cell lines successfully transfected with the empty lentiviral vector (Vector1, Vector2 and Vector3 cells) were obtained. Untransfected SACC-83 cells served as control (BLK) cells. Cell morphology under bright field and fluorescence was captured using an Eclipse TE2000-U fluorescence microscope (Nikon Corporation, Tokyo, Japan).

To knockdown $M Y B$ expression, SACC-83 and SACC-LM cells were transfected with $50 \mathrm{nM}$ small interfering (si)RNAs specific for $M Y B$ (siMYB) or negative control siRNAs (siNC; Guangzhou RiboBio Co., Ltd., Guangzhou, China) for $24 \mathrm{~h}$ using riboFECT ${ }^{\mathrm{TM}}$ CP Transfection kit (cat. no. C10511-1; Guangzhou RiboBio Co., Ltd.) according to the manufacturer's protocol. The $M Y B$ siRNA sequences are as follows: 5'-GGT CGAACAGGAAGGTTAT-3' (siMYB-1) and 5'-CAACCGA GAATGAGCTAAA-3' (siMYB-2). The NC siRNA sequence is 5'-TTTCTCCGAACGTGTCACG-3' (siNC).

Experimental animals. A total of 13 female non-obese diabetic/severe combined immunodeficiency (NOD/SCID) mice (5-6 weeks old) were purchased from Beijing Vital River Laboratory Animal Technology Co., Ltd. (Beijing, China). All animal experiments complied with the ARRIVE guidelines, and were conducted in accordance with the UK Animals (Scientific Procedures) Act, 1986 and associated guidelines as well as the EU Directive 2010/63/EU for animal experiments (30-32). These experiments were approved by the Peking University Institutional Animal Care and Use Committee (permit no. LA2015099).

Western blot analysis. SACC-83, NC, MYB OE, siNC, siMYB-1 and siMYB-2 cells were seeded in $100 \mathrm{~mm}$ dishes at $2 \times 10^{6}$ cells/dish and incubated in RPMI-1640 medium supplemented with $10 \% \mathrm{FBS}$ at $37^{\circ} \mathrm{C}$ in a humidified atmosphere containing $5 \% \mathrm{CO}_{2}$ for $48 \mathrm{~h}$. Cells were harvested, washed with ice-cold PBS and dissolved in ice-cold radioimmunoprecipitation assay buffer (Beijing Solarbio Science \& Technology Co., Ltd., Beijing, China) containing a protease inhibitor cocktail (Applygen Technologies, Inc., Beijing, China). The protein concentration was measured with a Pierce $^{\mathrm{TM}}$ Bicinchoninic Acid Protein Assay kit (Thermo Fisher Scientific, Inc.), following the manufacturer's protocol. The protein extracts (40 $\mu \mathrm{g} / \mathrm{lane})$ derived from each sample were separated by SDS-PAGE on 10-15\% gels and electroblotted onto polyvinylidene fluoride membranes. The membranes were blocked with 5\% non-fat milk in TBST (20 mM Tris, $137 \mathrm{mM} \mathrm{NaCl}$ and $0.1 \%$ Tween-20, $\mathrm{pH}$ 7.4) for $1 \mathrm{~h}$ at room temperature and then incubated with the following primary antibodies: Anti-MYB (cat. no. ab45150; Abcam, Cambridge, 
MA, USA), anti-E-cadherin (cat. no. 3195), anti-N-cadherin (cat. no. 13116), anti-vimentin (cat. no. 5741), anti-actin, aortic smooth muscle ( $\alpha$-SMA, encoded by ACTA2; cat. no. 19245), anti- $\beta$-catenin (cat. no. 8480; all Cell Signaling Technology, Inc., Danvers, MA, USA) and anti- $\beta$-actin (cat. no. ZM0001; OriGene Technologies, Inc., Beijing, China). Primary antibodies $(1: 1,000)$ were incubated for at least $1 \mathrm{~h}$ at $4^{\circ} \mathrm{C}$. Then, the membrane was washed extensively with TBST and incubated with secondary antibodies $(1: 10,000)$ for $1 \mathrm{~h}$ at room temperature. Horseradish peroxidase-conjugated goat anti-rabbit (cat. no. ZB-2301) or anti-mouse (cat. no. ZB-2305; both OriGene Technologies, Inc.) IgG antibodies were used as the secondary antibodies. The immunocomplexes were detected using SuperEnhanced chemiluminescence detection kit (cat. no. P1030-100; Applygen Technologies, Inc.). $\beta$-actin was used as the internal control. All bands were quantified using Adobe Photoshop CS5 Extended 12.0.3 x32, which was purchased from Adobe Systems Incorporated (San Jose, CA, USA). The MYB bands of SACC cells used in this experiment exhibited two bands; the two bands were counted in all the statistics. Three independent experiments with three biological replicates each were performed.

Cell proliferation assay. Cell proliferation was assessed by counting viable cells with Cell Counting Kit-8 (CCK8; Dojindo Molecular Technologies, Inc., Kumamoto, Japan). SACC-83, NC, MYB OE, Vector3, M1, M2, M3 cells and siMYB-1-, siMYB-2- and control siRNA-transfected cells were seeded into 96-well plates at a density of 3,000 cells/well in $100 \mu 1$ RPMI-1640 medium. At 24,48 and $72 \mathrm{~h}$, the absorbance of each well was measured at $450 \mathrm{~nm}$ using the ELx808 Absorbance Microplate Reader (BioTek Instruments, Inc., Winooski, VT, USA). For SACC-83, NC, MYB OE, Vector3, M1, M2, M3 cells, cell proliferation was compared by calculating the relative cell number because the initial density of the seeded cells was difficult to control. Relative cell number $=$ optical density (OD) 450 value per time point / OD 450 values at $0 \mathrm{~h}$. The data presented are representative of one of three replicates.

In vitro wound closure assay. After $12 \mathrm{~h}$ of FBS deprivation, confluent cell monolayers of BLK, Vector3, M1, M2 and M3 cells were scratched with a $200-\mu 1$ pipette tip to create wounded areas with widths of 400-600 $\mu \mathrm{m}$. Images were captured 0 and $1 \mathrm{~h}$ after scratching under an Eclipse TE2000-U fluorescence microscope (Nikon Corporation). The migrated distance was quantified by Integrated Performance Primitives software (version 6.0.0.260; Intel Corporation, Santa Clara, CA, USA). Three independent experiments were performed with three biological replicates each.

Transwell migration and invasion assays. To analyse Transwell migration and invasion, cell inserts $(8.0-\mu \mathrm{m}$ pore size; EMD Millipore, Billerica, MA, USA) were coated with (invasion) or without (migration) Matrigel (BD Bioscience). SACC-83, NC, MYB OE, Vector1, Vector2, Vector3, M1, M2 and M3 cell or siMYB-1-, siMYB-2- and siNC-transfected SACC-83 and SACC-LM cells were seeded at a density of $5 \times 10^{4}$ cells/well in RPMI-1640 medium without serum in the upper chamber. The lower chamber contained RPMI-1640 medium supplemented with $10 \%$ FBS. After $16 \mathrm{~h}$ of incubation, the cells on the upper surface of the insert were wiped off. The cells on the lower surface of the insert were fixed with 95\% ethanol for $30 \mathrm{~min}$ at room temperature, stained with $1 \%$ crystal violet for $40 \mathrm{~min}$ at room temperature and counted under a BX51 fluorescence microscope (Olympus Corporation, Tokyo, Japan) at a magnification of x20. Every experiment was repeated independently at least three times.

Mouse lung metastasis model. NOD/SCID mice were injected in the tail vein with $4 \times 10^{6}$ MYB OE $(n=7)$ or NC cells $(n=6)$. After 8 weeks, the mice were sacrificed and their lungs were collected. After the lungs were fixed with $4 \%$ paraformaldehyde for $24 \mathrm{~h}$ at room temperature, the lungs was embedded in paraffin and then cut into $4-\mu \mathrm{m}$-thick sections. The sections were used for hematoxylin and eosin staining.

Briefly, the sections were deparaffinized and rehydrated at $37^{\circ} \mathrm{C}$ with xylene I, xylene II and xylene III for 20 min each; then absolute ethanol I and absolute ethanol II for $10 \mathrm{~min}$ each; and finally 95, 80 and 70\% ethanol for 10, 4 and $2 \mathrm{~min}$, respectively. The sections were wash with deionized water three times for $3 \mathrm{~min}$ each time, then stained with hematoxylin for 2-3 min at room temperature. Next, differentiation was performed with hydrochloric acid alcohol for $1 \mathrm{sec}$, and then the sections were rinsed with deionized water for $10 \mathrm{~min}$ and stained with eosin for $8 \mathrm{~min}$ at room temperature. Gradient dehydration was performed at room temperature with 70,80 , 90, 95 and $100 \%$ ethanol for 2, 2, 3,3 and $10 \mathrm{~min}$, respectively, then with xylene I, xylene II and xylene III for 10 min each. The sections were sealed with neutral gum and placed in a ventilated room at room temperature overnight. The stained sections were evaluated by an experienced pathologist from the Department of Oral Pathology, Peking University School and Hospital of Stomatology.

Statistical analysis. All statistical analyses were conducted with SPSS (version 19.0; IBM Corp., Armonk, NY, USA). All in vitro experiments were performed at least three times and numerical data are presented as mean \pm standard deviation of three independent experiments. P-values were calculated by a two-tailed unpaired Student's t-test or one-way analysis of variance with Bonferroni post-test correction. The results were confirmed in at least three independent experiments. $\mathrm{P}<0.05$ indicated that the difference between groups was statistically significant. The Pearson correlation coefficient was calculated to evaluate the correlation of MYB with E-cadherin or vimentin.

\section{Results}

MYB is overexpressed in SACC tissue samples and associated with the potential for metastasis in clinical cases. As presented in Fig. 1A, MYB was 11 th among the top 15 upregulated mRNAs in the 10 human SACC and paired SMG tissues in the microarray analysis. The mRNA expression levels of $M Y B$ and EMT-associated markers were also measured in 50 fresh frozen SACC tissues and 41 normal fresh frozen SMG tissues using RT-qPCR. MYB expression was significantly higher in the SACC tissues compared with the normal SMG tissues, with a high expression rate of $90 \%$ (Fig. 1B). The clinicopathological features of the SACC patients are stratified 

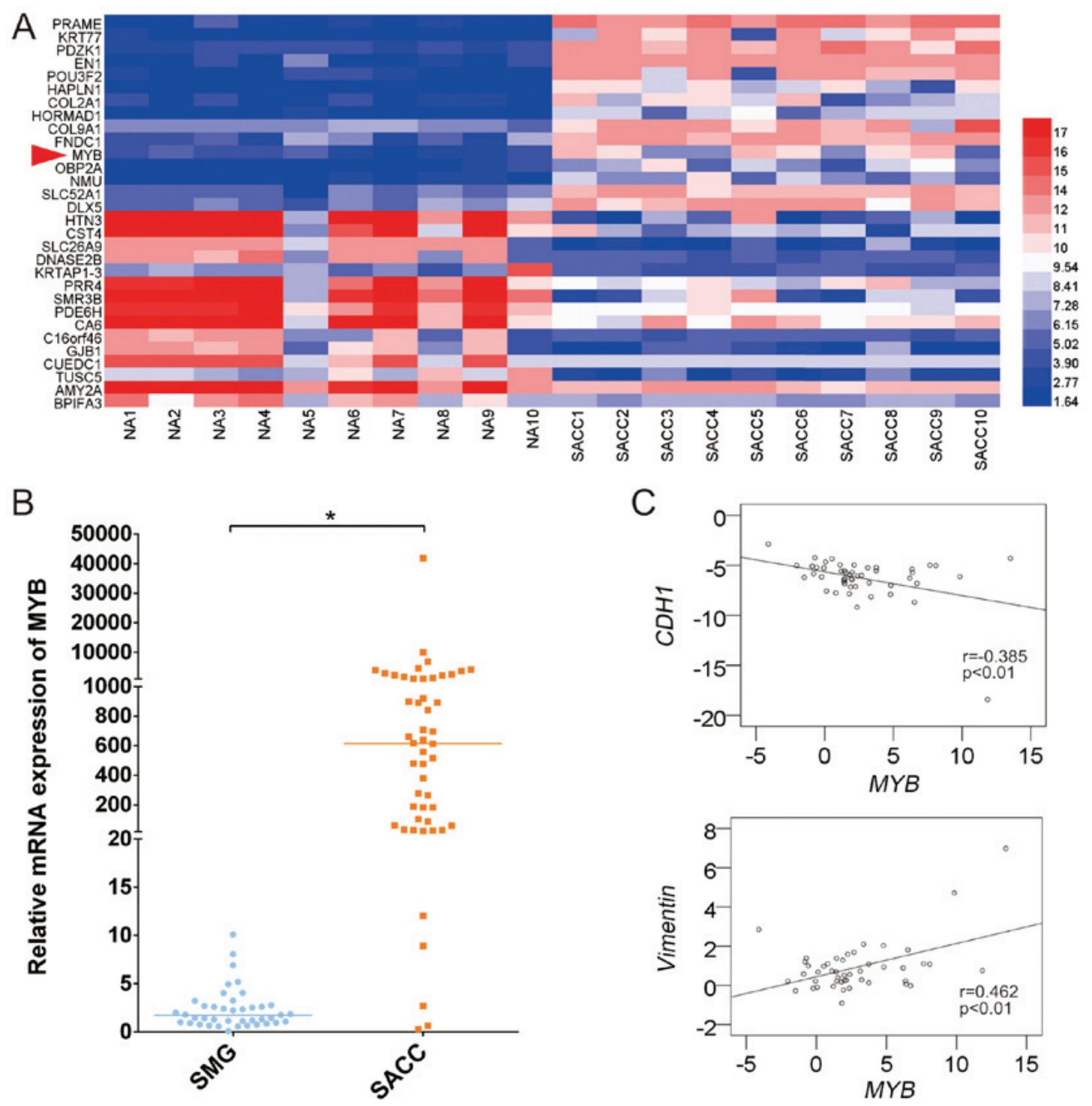

Figure 1. MYB is overexpressed in SACC tissues and correlates with the SACC metastatic potential. (A) Microarray screening of differentially expressed mRNAs in 10 human SACC tissues and paired SMG tissues. The key represents relative mRNA expression. The heatmaps presented the 15 most upregulated mRNAs and the 15 most downregulated mRNAs. (B) Reverse transcription-quantitative polymerase chain reaction analysis of $M Y B$ overexpression in 50 human SACC and 41 SMG tissues. (C) Correlation of $M Y B$ mRNA expression with $C D H 1$ and vimentin mRNA expression in SACC tissues (n=50). SACC, salivary adenoid cystic carcinoma; SMG, submandibular gland; $M Y B$, transcriptional activator Myb gene; $C D H 1$, cadherin-1.

in Table I. A total of 50 SACC patients were classified into the high or low $M Y B$ group depending on the median $M Y B$ level. High $M Y B$ expression was correlated with the pathological type, lung metastasis and clinical stage. Although high $M Y B$ expression did not significantly correlate with tumour size, the P-value was close to the threshold. No correlation was identified between $M Y B$ expression and the other parameters, including age, sex, site, lymph node metastasis, perineural invasion and local regional recurrence.

CDH1 and vimentin expression was also measured by RT-qPCR in these SACC tissues, and the correlation of $M Y B$ with $C D H 1$ and vimentin was analysed. $M Y B$ tended to be significantly and negatively correlated with $\mathrm{CDH} 1$, and significantly and positively correlated with vimentin (Fig. 1C).

MYB is overexpressed in SACC cells and modulates cell proliferation in vitro. To explore the biological role of $M Y B$ in SACC cells, MYB expression was measured in SACC-83 cells, primary cells derived from a human SMG tissue (pSMG cells) and a subset of SACC cells that exhibited high lung metastasis (SACC-LM cells). MYB mRNA expression levels were significantly higher and $M Y B$ protein expression levels were markedly higher in the SACC-83 and SACC-LM cells compared with in the pSMG cells (Fig. 2A). MYB mRNA expression levels were significantly higher and $M Y B$ protein expression levels were markedly higher in the SACC-LM cells compared with the SACC-83 cells, indicating that MYB is associated with SACC oncogenesis and metastasis.

$M Y B$ mRNA expression levels were significantly higher in the MYB OE cells compared with NC and BLK cells, demonstrating that $M Y B$ overexpressing vector transfection was stable (Fig. 2B). $M Y B$ protein expression levels were markedly higher in the MYB OE cells compared with NC and BLK cells. The $M Y B$ mRNA expression levels were significantly higher in the M1, M2 and M3 cells compared with the Vector3 cells, while protein expression levels were 
A

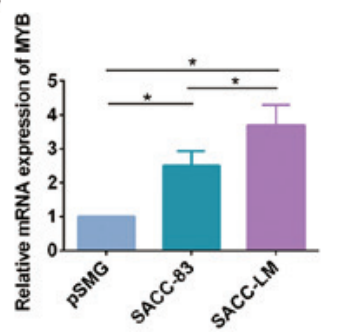

$\mathrm{B} \stackrel{0}{\mathrm{~s}}$
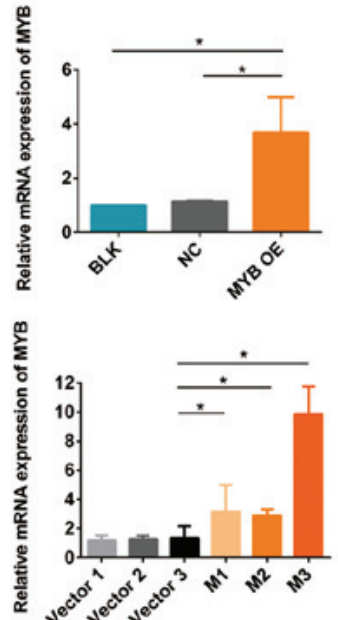

$\mathrm{D}$
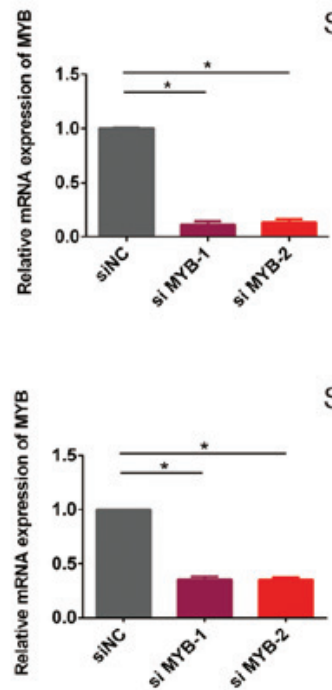
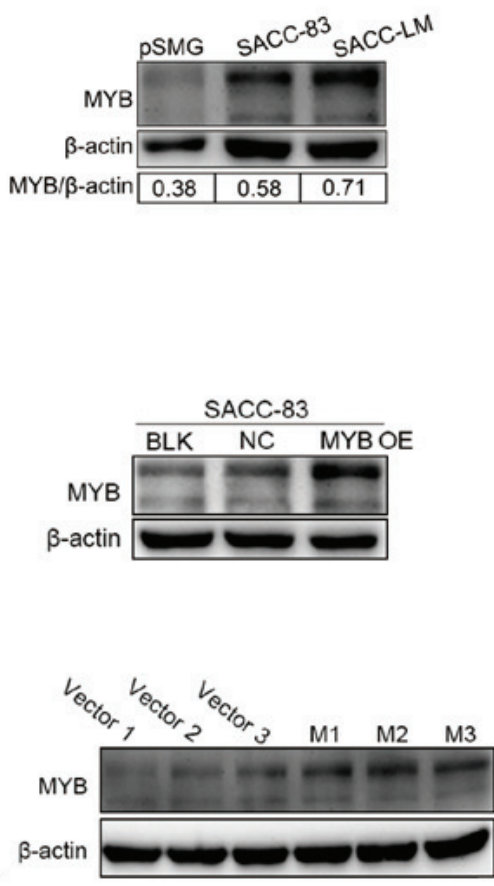

SACC-83

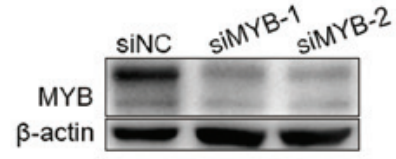

SACC-LM

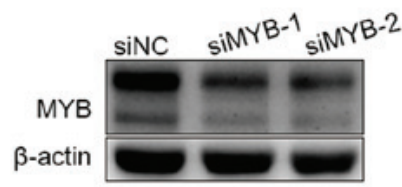

C

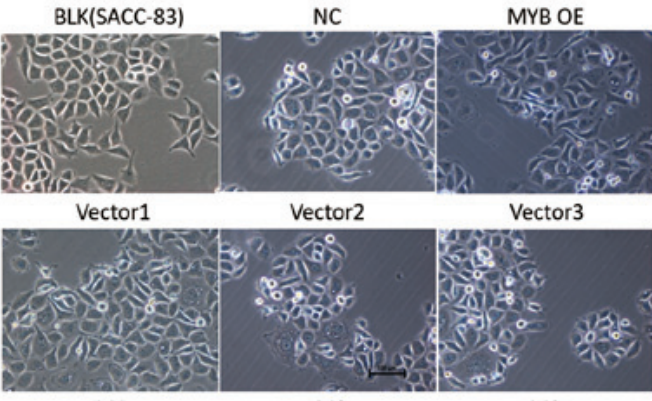

M2

M3

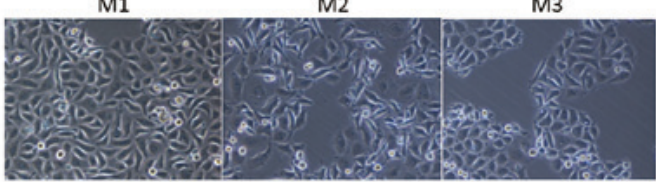

BLK(SACC-83)

MYB OE

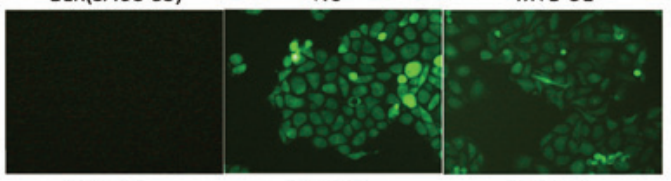

Vector1

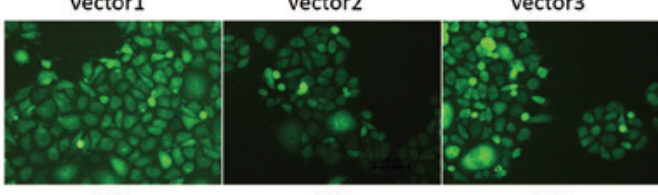

$\mathrm{M} 2$

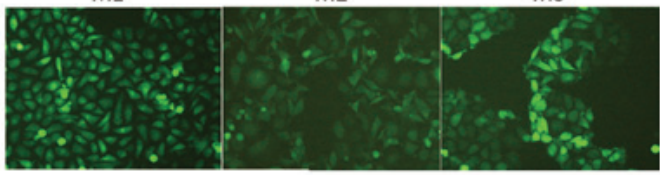

E
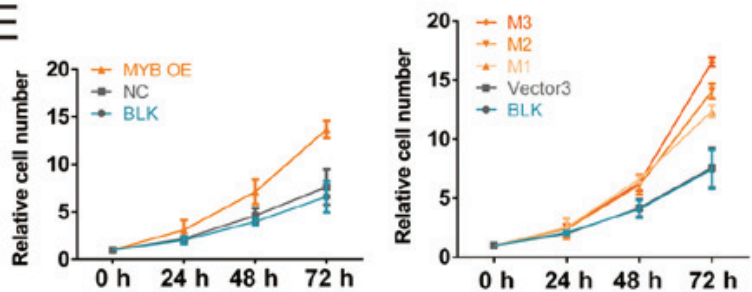

F

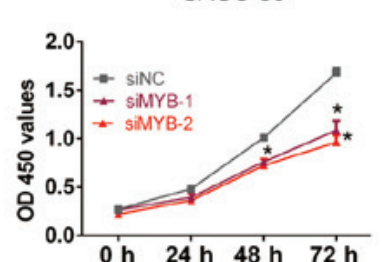

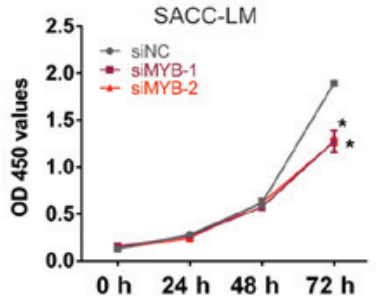

Figure 2. MYB is overexpressed in SACC cells, which promotes SACC cell proliferation, and its knockdown inhibits SACC cell proliferation. (A) RT-qPCR analysis of MYB mRNA expression and western blot analysis of MYB protein expression in pSMG, SACC-83 and SACC-LM cells ("P<0.05 as defined). (B) RT-qPCR analysis of MYB mRNA expression and western blot analysis of MYB protein expression in transfected SACC- 83 cells ("P<0.05 as defined) (C) Fluorescence microscopy in transfected SACC-83 and BLK cells. (D) RT-qPCR analysis of MYB mRNA expression and western blot analysis of MYB protein expression in siNC-, siMYC-1- and siMYC-2-transfected SACC-83 and SACC-LM cells ("P<0.05 as defined). (E) Cell proliferation of the transfected SACC-83 cells, including BLK, NC, MYB OE, Vector3, M1, M2 and M3 cells. Cell proliferation was assessed using the Cell Counting Kit-8 assay and compared by calculating the relative cell number. Relative cell number = OD 450 values per time point / OD 450 values of 0 h. (F) Proliferation of siNC-, siMYC-1- and siMYC-2-transfected SACC-83 and SACC-LM cells was assessed using the Cell Counting Kit-8 assay. Data are presented as mean \pm standard deviation of three independent experiments ("P<0.05 vs. siNC). RT-qPCR, reverse transcription-quantitative polymerase chain reaction analysis; pSMG, primary cells derived from the human submandibular gland; SACC, salivary adenoid cystic carcinoma; $M Y B$, transcriptional activator Myb gene; NC, cells transfected with an empty vector; MYB OE, $M Y B$ overexpressing cells; M, cells derived from $M Y B$ overexpressing cells; Vector, cells derived from NC cells; si, small interfering RNA; siNC, cells transfected with a negative control siRNA; siMYB, cells transfected with a siRNA against MYB; BLK, untransfected cells; OD, optical density.

markedly higher in the M1, M2 and M3 cells compared with the Vector 3 cells. Fibroblastic morphological changes of the cells undergoing EMT were identified in $M Y B$ overexpressing cells. Microscopic observation revealed the cobblestone-like 

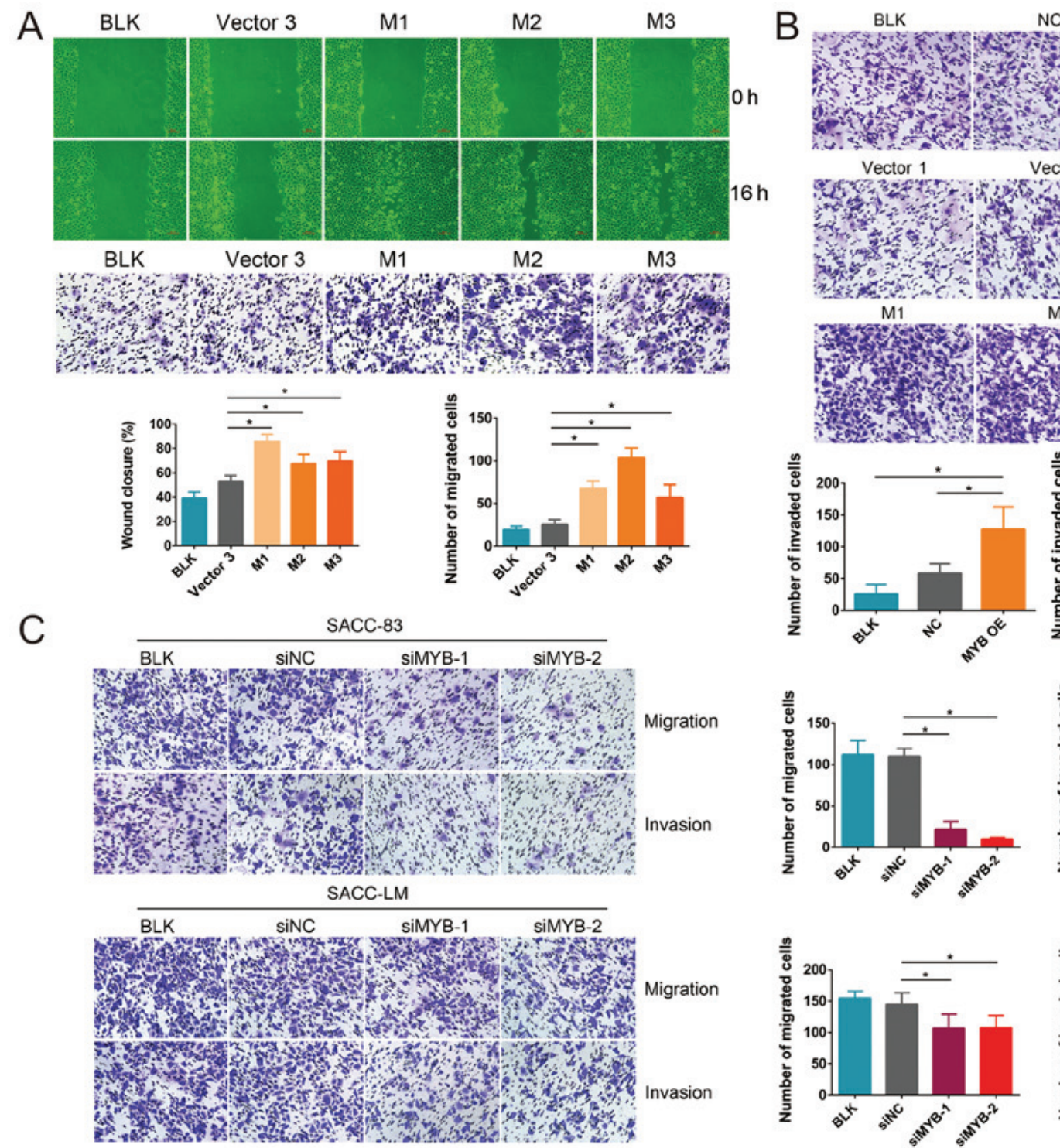

NC MYB OE
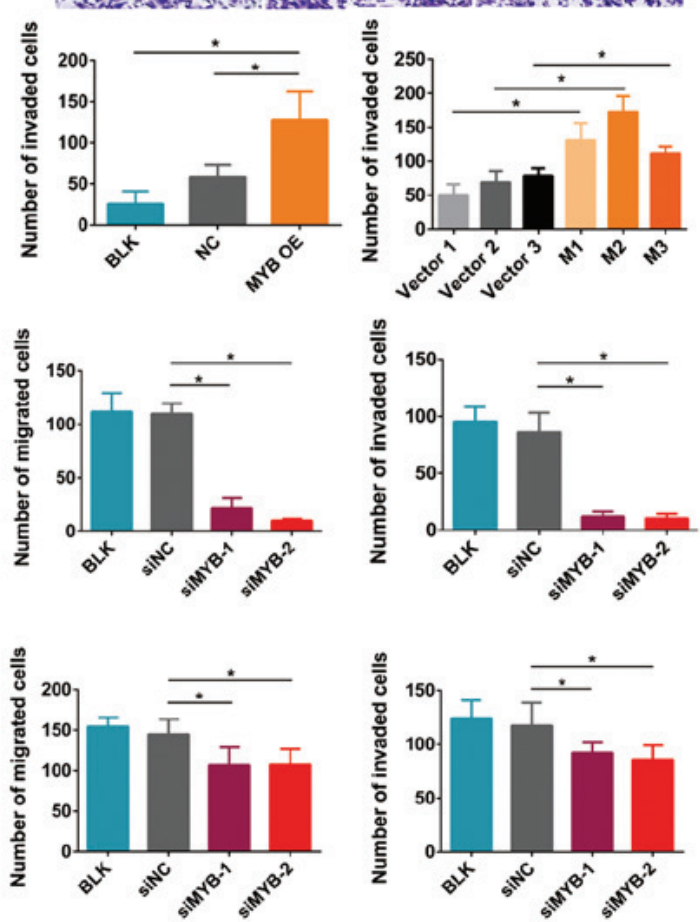

Figure 3. $M Y B$ overexpression promotes and $M Y B$ knockdown inhibits the migration and invasion of SACC cells. (A) Wound closure and Transwell migration assays of M1-, M2-, M3- and Vector3-transfected, and BLK SACC-83 cells. (B) Transwell invasion assay of transfected SACC-83 cells and BLK SACC-83 cells. (C) Transwell migration and invasion assays of siNC-, MYB-1- and MYB-2-transfected, and BLK SACC-83 cells. Data are presented as mean \pm standard deviation of three independent experiments ( $\mathrm{P}<0.05)$. SACC, salivary adenoid cystic carcinoma; $M Y B$, transcriptional activator Myb gene; NC, cells transfected with an empty vector; M, cells derived from $M Y B$ overexpressing cells; Vector, cells derived from NC cells; si, small interfering RNA; siNC, cells transfected with a negative control siRNA; siMYB, cells transfected with a siRNA against MYB; BLK, untransfected cells.

structure of BLK, NC, Vector1, Vector2 and Vector3 cells. MYB OE, M1, M2 and M3 cells exhibited varying degrees of fibroblastic changes (Fig. 2C). Approximately $90 \%$ of MYB OE, M1 and M2 cells and 40\% of M3 cells lost their original polygonal phenotype and acquired a fibroblastic phenotype. $M Y B$ expression was knocked down in the SACC-83 and SCC-LM cell lines using siMYB-1 and siMYB-2 (Fig. 2D). The MYB mRNA expression levels were significantly lower and $M Y B$ protein expression levels were markedly lower in the siMYB-1 and siMYB-2 cells compared with the siNC cells.

The proliferation ability of MYB OE, M1, M2 and M3 cells was markedly higher compared with control cells at $72 \mathrm{~h}$ (Fig. 2E). The cell proliferation assay demonstrated that SACC cell growth was inhibited in the two cell lines (Fig. 2F). The proliferation was significantly attenuated in siMYB-1 and
siMYB-2 cells compared with the siNC cells. Together, these findings support a growth-promoting role for MYB in SACC cells.

MYB promotes SACC cell migration and invasion in vitro. To investigate the effect of $M Y B$ expression on the aggressiveness of SACC cells, the effect of $M Y B$ on cell migration and invasion was studied. The wound healing and Transwell migration assays demonstrated that the migration of M1, M2 and M3 cells was significantly higher compared with the Vector3 cells (Fig. 3A). Additionally, the Transwell invasion assay demonstrated that the invasive ability of the MYB OE cells was significantly greater compared with that of the NC and BLK cells (Fig. 3B). Similarly, the M1, M2 and M3 cells had significantly higher invasive abilities compared with the Vector1, Vector2 and Vector3 cells, respectively. 


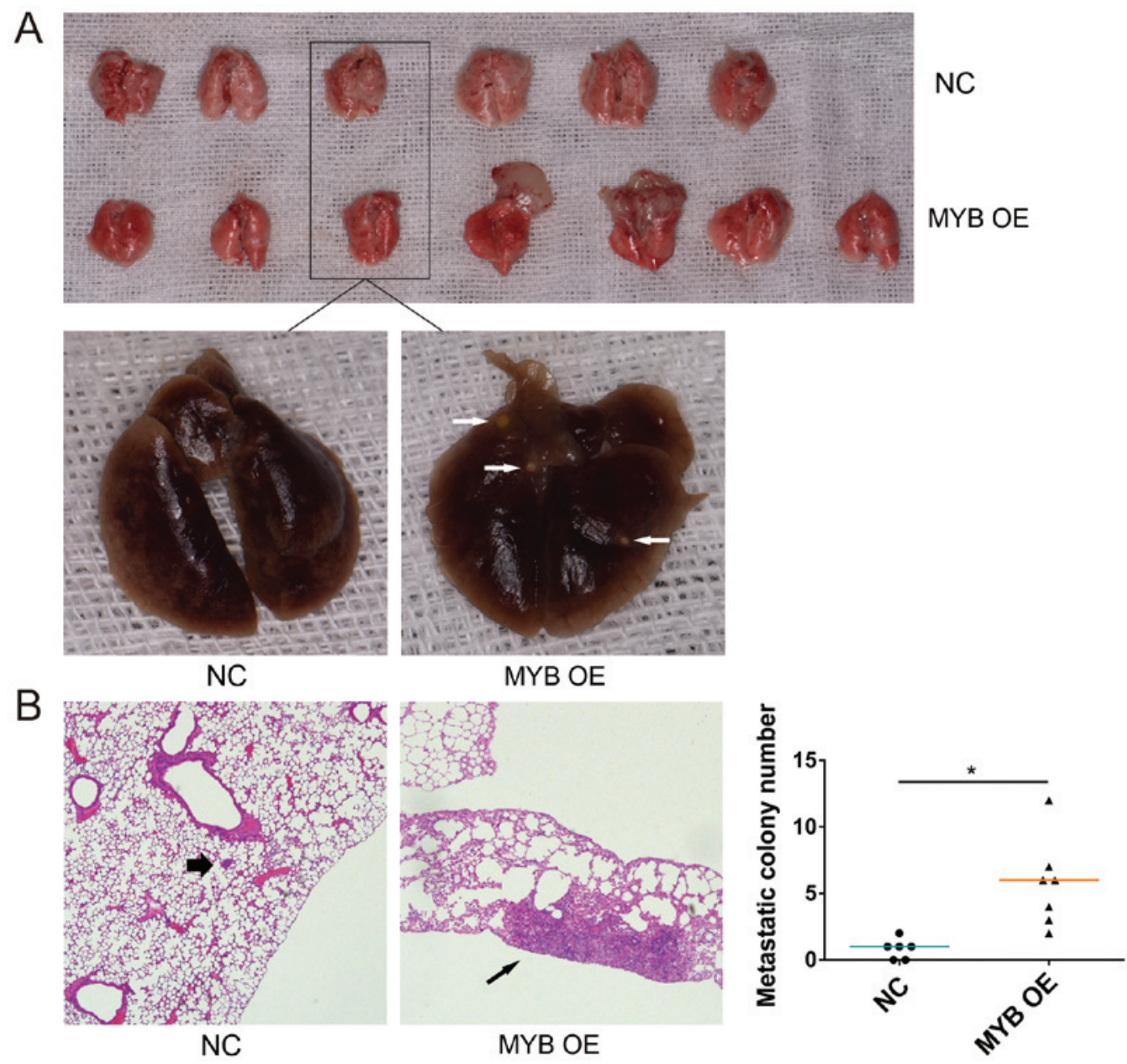

Figure 4. MYB promotes salivary adenoid cystic carcinoma lung metastasis in vivo. Lung tissues from mice injected intravenously with NC and MYB OE cells were removed after 8 weeks and observed. (A) Images of xenograft model mice. The arrows indicate metastatic tumour nodules. (B) Images of haematoxylin and eosin staining metastatic tumour nodules in the lung tissues and quantification of metastatic colony number $($ "P $<0.05)$. NC, mice injected with negative control-transfected cells; MYB OE, mice injected with transcriptional activator Myb overexpressing cells.

In contrast, the knockdown of $M Y B$ by siMYB-1 and siMYB-2 in the SACC-83 and SACC-LM cells significantly inhibited cell migration and invasion compared with the siNC cells (Fig. 3C). These results indicated that $M Y B$ overexpression promoted SACC cell migration and invasion, whereas $M Y B$ knockdown inhibited SACC cell migration and invasion.

$M Y B$ promotes $S A C C$ lung metastasis in vivo. To investigate the effect of MYB on SACC lung metastasis, MYB OE and NC cells were injected into NOD/SCID mice through the tail vein. The lung tissues were collected from all mice after 8 weeks. The mice injected with MYB OE cells had visible tumour nodules, which were not observed in the NC cell-injected mice (Fig. 4A). The number of tumour nodules in the lungs of the mice injected with MYB OE cells was significantly greater compared with that of the NC cells based on hematoxylin and eosin staining of the lung tissues (Fig. 4B). These results indicated that MYB promoted SACC lung metastasis in vivo.

MYB modulates the expression of genes associated with proliferation and metastasis. To explore the molecular mechanism underlying MYB-induced tumour promotion and metastasis, genes associated with tumour progression and metastasis were examined in NC, MYB OE, siNC and siMYB-1 cells by RT-qPCR. Significant changes were identified in five of the 22 genes (data not shown). The expression of $C C N D 1$ and $M C L 1$, which are associated with cell proliferation $(33,34)$, was upregulated following $M Y B$ overexpression, whereas $p 21$ expression was downregulated (Fig. 5A). ICAM1, VEGFA, MMP7 and MMP9, which are involved in cell migration and invasion $(24,25,35,36)$, were upregulated following $M Y B$ overexpression. In addition, CCND1, MCL1, ICAM1, VEGFA, MMP7 and MMP9 were downregulated, whereas $p 21$ was upregulated following MYB knockdown (Fig. 5B). Taken together, these findings indicate that $M Y B$ promotes the growth, migration and invasion of SACC cells by regulating the expression of genes involved in proliferation and metastasis.

$M Y B$ regulates EMT in SACC cells. As mentioned previously, MYB tends to be negatively correlated with the epithelial marker, E-cadherin, and positively correlated with the mesenchymal marker, vimentin. The expression of E-cadherin 

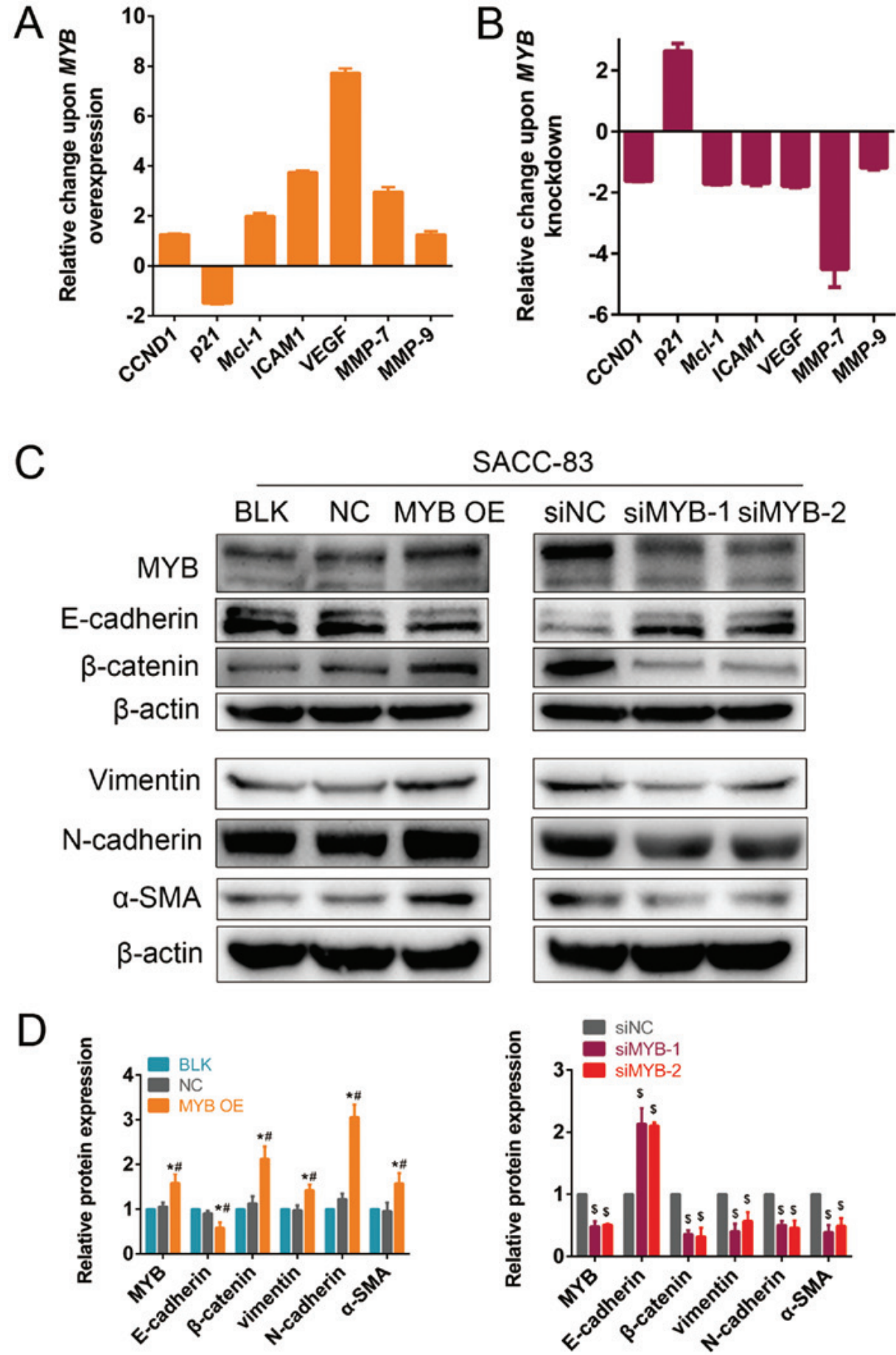

Figure 5. MYB modulates the expression of genes associated with proliferation and metastasis. Quantification of RT-qPCR analysis expression following $M Y B$ (A) overexpression and (B) knockdown in SACC-83 cells. (C) Western blotting of transfected and BLK SACC-83 cells. (D) Quantification of protein bands in transfected and BLK SACC-83 cells. Data are presented as mean \pm standard deviation of three independent experiments ("P $<0.05$ vs. NC; ${ }^{\# P}<0.05$ vs. BLK; ${ }^{\$} \mathrm{P}<0.05$ vs. siNC). SACC, salivary adenoid cystic carcinoma; $M Y B$, transcriptional activator Myb gene; MYB, transcriptional activator Myb protein; NC, cells transfected with an empty vector; si, small interfering RNA; siNC, cells transfected with a negative control siRNA; siMYB, cells transfected with a siRNA against MYB; BLK, untransfected cells; $C C N D 1, \mathrm{G1} / \mathrm{S}$-specific cyclin-D1 gene; $p 21$, cyclin-dependent kinase inhibitor 1 gene; $M C L 1$, myeloid leukemia cell differentiation protein Mcl-1 gene; ICAM1, intercellular adhesion molecule 1 gene; VEGFA, vascular endothelial growth factor A gene; $M M P$, matrix metalloproteinase gene; E-cadherin, cadherin-1; $\beta$-catenin, catenin $\beta$-1; N-cadherin, cadherin-2; $\alpha$-SMA, actin, aortic smooth muscle.

in the MYB OE group was significantly downregulated following $M Y B$ overexpression compared with the BLK and $\mathrm{NC}$ groups, whereas $\mathrm{N}$-cadherin, vimentin and $\alpha$-SMA expression was significantly upregulated (Fig. 5C and D). $\beta$-catenin, which is the key molecule of the canonical Wnt signalling pathway (18), was also significantly upregulated following $M Y B$ overexpression compared with the BLK and NC groups, suggesting that MYB may regulate EMT via the Wnt signalling pathway. Additionally, E-cadherin was significantly upregulated, and $\mathrm{N}$-cadherin, vimentin, $\alpha$-SMA and $\beta$-catenin were significantly downregulated in the siMYB-1- and siMYB-1-transfected cells compared with the siNC group. 


\section{Discussion}

In the current study, $M Y B$ expression was measured in 50 fresh frozen SACC tissues and 41 fresh frozen SMG tissues, and the clinicopathological features of the SACC patients were stratified. In particular, it was determined that MYB was closely associated with lung metastasis and was associated with the pathological tumour type in patients with SACC $(14,18)$. MYB expression was significantly greater in SACC tissues compared with normal SMG tissues, with an expression rate of $90 \%$. This result was consistent with that of previous studies $(12,14)$, but the proportion of $M Y B$ overexpression seemed to be higher in the current study. These results evidently suggest that MYB serves an important role in SACC.

To explore the effect of MYB in SACC, overexpression and knockdown of MYB in SACC cells was performed and cell proliferation was explored using CCK8. The results demonstrated that upregulation of $M Y B$ increased the relative number of cells, which was consistent with previous findings in prostate and pancreatic cancer $(37,38)$. Knockdown of $M Y B$ significantly inhibited cell proliferation, which was similar to findings for acute myeloid leukaemia, chronic myeloid leukaemia and colon cancer $(39,40)$. Mechanistically, previous studies demonstrated that $M Y B$ induced the growth of tumour cells through the promotion of cell cycle progression, which was associated with cell proliferation $(41,42)$. It has been suggested that MYB is capable of regulating various genes responsible for tumorigenesis in multiple cancers $(17,35,43,44)$. Using RT-qPCR, the authors of the current study revealed that MYB may improve cell proliferation by enhancing cell cycle progression through $C C N D 1$ upregulation and $p 21$ downregulation. Additionally, MYB may decrease apoptosis by upregulating $M C L 1$ expression, which encodes proteins belonging to the Bcl-2 family (34).

Apart from its effect on tumour cell growth, MYB also has been revealed to promote a variety of phenotypes associated with the migration and invasion of cancer cells $(18,41,42,45,46)$. Similarly, in the current study, MYB significantly enhanced SACC cell migration and invasion in in vivo and in vitro experiments. Previous studies demonstrated that VEGF promoted metastasis via angiogenesis $(24,25,47)$. The current study demonstrated that $V E G F A$ was upregulated in $M Y B$ overexpressing SACC cells, indicating that MYB could increase the metastasis of SACC cells by increasing VEGFA expression. In addition, MYB was demonstrated to increase the ICAMI level, which encodes intercellular adhesion molecules that can promote tumour metastasis (48). MMP7 and $M M P 9$ are involved in angiogenesis and tumor metastasis $(45,49)$. The current study revealed that MMP-7 and MMP-9 were upregulated in $M Y B$ overexpressing SACC cells, indicating that MYB could increase the metastasis of SACC cells by increasing $M M P 7$ and $M M P 9$ expression. However, the corresponding protein levels of these RNAs were not assessed in the current study, which is a limitation.

Tumour metastasis depends on the occurrence of EMT, including decreased expression of cell adhesion molecules, such as E-cadherin, and increased expression of mesenchymal markers, including $\mathrm{N}$-cadherin and vimentin (22-24). In SACC tissues, $M Y B$ tended to be negatively correlated with
$\mathrm{CDH} 1$ and positively correlated with vimentin. Additionally, the authors revealed that, in SACC cells, MYB upregulated EMT-associated markers, including vimentin, $\mathrm{N}$-cadherin and $\alpha$-SMA, which was similar to the results of previous reports investigating breast cancer $(18,50)$. These results indicated that MYB regulated SACC metastasis by promoting the EMT.

In conclusion, MYB regulated proliferation-associated molecules, including $C C N D 1, p 21$ and $M C L 1$, in SACC cells to enhance cell proliferation. MYB also regulated ICAMI, VEGFA, MMP7, MMP9 and EMT-associated markers, including E-cadherin, vimentin, $\mathrm{N}$-cadherin and $\alpha$-SMA, in SACC cells to increase metastasis. In addition, MYB promoted SACC lung metastasis in a xenograft mouse model. Specifically, it was determined that MYB was closely associated with lung metastasis and the pathological tumour type in patients with SACC, which has rarely been reported. The results of the current study suggest that MYB may be an important therapeutic target for SACC.

\section{Acknowledgements}

The authors would like to thank Dr Lei Chen from the Department of Endocrinology (Peking University First Hospital, Beijing, China) for proofreading the article.

\section{Funding}

The current study was supported by the National Natural Science Foundation of China (grant nos. 81272966 and 81272967).

\section{Availability of data and materials}

The datasets used and/or analysed during the current study are available from the corresponding author upon reasonable request.

\section{Authors' contributions}

LHX, XYG and SLL conceived and designed the experiments. LHX and FZ performed the experiments and acquired the data. LHX, WWY and CWC analysed and interpreted the data. LHX, ZHD and MF performed the statistical analysis. LHX wrote the manuscript. All authors edited the final manuscript. All authors read and approved the final manuscript.

\section{Ethics approval and consent to participate}

The collection and use of human tissue samples was approved by the Ethics Committee of Peking University School and Hospital of Stomatology (Beijing, China; permit no. PKUSSIRB-201522040). All animal experiments complied with the ARRIVE guidelines and were performed in accordance with the U.K. Animals (Scientific Procedures) Act, 1986 and associated guidelines and the EU Directive 2010/63/EU for animal experiments. These experiments were approved by the Peking University Institutional Animal Care and Use Committee (Beijing, China; permit no. LA2015099). Written informed consent was provided by all patients. 


\section{Patient consent for publication}

Not applicable.

\section{Competing interests}

The authors declare that they have no competing interests.

\section{References}

1. Kokemueller H, Eckardt A, Brachvogel P and Hausamen JE: Adenoid cystic carcinoma of the head and neck - a 20 years experience. Int J Oral Maxillofac Surg 33: 25-31, 2004

2. Gondivkar SM, Gadbail AR, Chole R and Parikh RV: Adenoid cystic carcinoma: A rare clinical entity and literature review. Oral Oncol 47: 231-236, 2011.

3. van Weert S, Bloemena E, van der Waal I, de Bree R, Rietveld DH Kuik JD and Leemans CR: Adenoid cystic carcinoma of the head and neck: A single-center analysis of 105 consecutive cases over a 30-year period. Oral Oncol 49: 824-829, 2013

4. Liu J, Shao C, Tan ML, Mu D, Ferris RL and Ha PK: Molecular biology of adenoid cystic carcinoma. Head Neck 34: 1665-1677, 2012.

5. Grimm M, Henopp T, Hoefert S, Schaefer F, Kluba S, Krimmel M and Reinert S: Multiple osteolytic lesions of intraosseous adenoid cystic carcinoma in the mandible mimicking apical periodontitis. Int Endod J 45: 1156-1164, 2012.

6. Wal JE, Becking AG, Snow GB and van der Waal I: Distant metastases of adenoid cystic carcinoma of the salivary glands and the value of diagnostic examinations during follow-up. Head Neck 24: 779-783, 2002.

7. Huang Y, Yu T, Fu X, Chen J, Liu Y, Li C, Xia Y, Zhang Z and Li L: EGFR inhibition prevents in vitro tumor growth of salivary adenoid cystic carcinoma. BMC Cell Biol 14: 13, 2013.

8. Jaso J and Malhotra R: Adenoid cystic carcinoma. Arch Pathol Lab Med 135: 511-515, 2011.

9. Persson M, Andrén Y, Mark J, Horlings HM, Persson F and Stenman G: Recurrent fusion of MYB and NFIB transcription factor genes in carcinomas of the breast and head and neck. Proc Natl Acad Sci USA 106: 18740-18744, 2009.

10. Brill LB II,KannerWA,Fehr A, Andrén Y,Moskaluk CA,Löning T, Stenman G and Frierson HF Jr: Analysis of MYB expression and MYB-NFIB gene fusions in adenoid cystic carcinoma and other salivary neoplasms. Mod Pathol 24: 1169-1176, 2011.

11. Persson M, Andrén Y, Moskaluk CA, Frierson HF Jr, Cooke SL, Futreal PA, Kling T, Nelander S, Nordkvist A, Persson F, et al: Clinically significant copy number alterations and complex rearrangements of MYB and NFIB in head and neck adenoid cystic carcinoma. Genes Chromosomes Cancer 51: 805-817, 2012.

12. Mitani Y, Li J, Rao PH, Zhao YJ, Bell D, Lippman SM, Weber RS, Caulin $\mathrm{C}$ and El-Naggar AK: Comprehensive analysis of the MYB-NFIB gene fusion in salivary adenoid cystic carcinoma: Incidence, variability, and clinicopathologic significance. Clin Cancer Res 16: 4722-4731, 2010.

13. Brayer KJ, Frerich CA, Kang H and Ness SA: Recurrent fusions in MYB and MYBL1 define a common, transcription factor-driven oncogenic pathway in salivary gland adenoid cystic carcinoma. Cancer Discov 6: 176-187, 2016.

14. West RB, Kong C, Clarke N, Gilks T, Lipsick JS, Cao H, Kwok S, Montgomery KD, Varma S and Le QT: MYB expression and translocation in adenoid cystic carcinomas and other salivary gland tumors with clinicopathologic correlation. Am J Surg Pathol 35: 92-99, 2011.

15. Argyris PP, Wetzel SL, Greipp P, Wehrs RN, Knutson DL, Kloft-Nelson SM, García JJ and Koutlas IG: Clinical utility of myb rearrangement detection and p63/p40 immunophenotyping in the diagnosis of adenoid cystic carcinoma of minor salivary glands: A pilot study. Oral Surg Oral Med Oral Pathol Oral Radiol 121: 282-289, 2016.

16. Belloni E, Shing D, Tapinassi C, Viale A, Mancuso P, Malazzi O, Gerbino E, Dall'Olio V, Egurbide I, Odero MD, et al: In vivo expression of an aberrant MYB-GATA1 fusion induces leukemia in the presence of GATA1 reduced levels. Leukemia 25: 733-736, 2011.

17. Ramsay RG and Gonda TJ: MYB function in normal and cancer cells. Nat Rev Cancer 8: 523-534, 2008
18. Li Y, Jin K, van Pelt GW, van Dam H, Yu X, Mesker WE, Ten Dijke P, Zhou F and Zhang L: c-Myb enhances breast cancer invasion and metastasis through the Wnt/ $\beta$-catenin/Axin2 pathway. Cancer Res 76: 3364-3375, 2016.

19. Costa AF, Altemani A, García-Inclán C, Fresno F, Suárez C, Llorente JL and Hermsen M: Analysis of MYB oncogene in transformed adenoid cystic carcinomas reveals distinct pathways of tumor progression. Lab Invest 94: 692-702, 2014.

20. Dong L, Wang YX, Li SL, Yu GY, Gan YH, Li D and Wang CY: TGF-betal promotes migration and invasion of salivary adenoid cystic carcinoma. J Dent Res 90: 804-809, 2011.

21. Gibbons DL and Creighton CJ: Pan-cancer survey of epithelial-mesenchymal transition markers across the Cancer Genome Atlas. Dev Dyn 247: 555-564, 2018.

22. Kalluri R and Weinberg RA: The basics of epithelial-mesenchymal transition. J Clin Invest 119: 1420-1428, 2009.

23. Yang MH, Hsu DS, Wang HW, Wang HJ, Lan HY, Yang WH, Huang CH, Kao SY, Tzeng CH, Tai SK, et al: Bmil is essential in Twist1-induced epithelial-mesenchymal transition. Nat Cell Biol 12: 982-992, 2010.

24. Thiery JP, Acloque H, Huang RYJ and Nieto MA: Epithelial-mesenchymal transitions in development and disease. Cell 139: 871-890, 2009.

25. Yang WW, Yang LQ, Zhao F, Chen CW, Xu LH, Fu J, Li SL and Ge XY: Epiregulin promotes lung metastasis of salivary adenoid cystic carcinoma. Theranostics 7: 3700-3714, 2017.

26. Levene A: International Histological Classification of Tumours No. 7 Histological Typing of Salivary Gland Tumours. J Clin Pathol 26: 895, 1973 .

27. Livak KJ and Schmittgen TD: Analysis of relative gene expression data using real-time quantitative PCR and the 2(- Delta C(T)) Method. Methods 25: 402-408, 2001.

28. Li SL: Establishment of a human cancer cell line from adenoid cystic carcinoma of the minor salivary gland. Zhonghua Kou Qiang Yi Xue Za Zhi. 25: 29-31, 1990 (In Chinese).

29. Du ZH, Li SL, Ge XY, Yu GY and Ding C: Comparison of the secretory related molecules expression in stem cells from the pulp of human exfoliated deciduous teeth and dental pulp stem cells. Zhonghua Kou Qiang Yi Xue Za Zhi 53: 741-747, 2018 (In Chinese).

30. Kilkenny C, Browne WJ, Cuthill IC, Emerson M and Altman DG: Improving bioscience research reporting: The ARRIVE guidelines for reporting animal research. Osteoarthritis Cartilage 20: 256-260, 2012.

31. Hollands C: The Animals (scientific procedures) Act 1986 Lancet 2: 32-33, 1986.

32. Grignaschi G, Redaelli V, Luzi F and Fornasier M: The bodies in charge of animal welfare: What they do and what they could do? Front Physiol 9: 391, 2018.

33. Ramos-García P, Gil-Montoya JA, Scully C, Ayén A, González-Ruiz L, Navarro-Triviño FJ and González-Moles MA: An update on the implications of cyclin D1 in oral carcinogenesis. Oral Dis 23: 897-912, 2017.

34. Xiang W, Yang CY and Bai L: MCL-1 inhibition in cancer treatment. OncoTargets Ther 11: 7301-7314, 2018.

35. Quintana AM, Liu F, O'Rourke JP and Ness SA: Identification and regulation of $\mathrm{c}-\mathrm{Myb}$ target genes in MCF-7 cells. BMC Cancer 11: 30, 2011

36. Huang H: Matrix metalloproteinase-9 (MMP-9) as a cancer biomarker and MMP-9 biosensors: Recent advances. Sensors (Basel) 18: 18, 2018.

37. Srivastava SK, Bhardwaj A, Arora S, Singh S, Azim S, Tyagi N, Carter JE, Wang B and Singh AP: MYB is a novel regulator of pancreatic tumour growth and metastasis. Br J Cancer 113: 1694-1703, 2015 .

38. Srivastava SK, Bhardwaj A, Singh S, Arora S, McClellan S, Grizzle We, Reed E and Singh AP: Myb overexpression overrides androgen depletion-induced cell cycle arrest and apoptosis in prostate cancer cells, and confers aggressive malignant traits: Potential role in castration resistance. Carcinogenesis 33: 1149-1157, 2012.

39. Pattabiraman DR and Gonda TJ: Role and potential for therapeutic targeting of MYB in leukemia. Leukemia 27: 269-277, 2013

40. Cheasley D, Pereira L, Sampurno S, Sieber O, Jorissen R, Xu H, Germann M, Yuqian Y, Ramsay RG and Malaterre J: Defective Myb function ablates cyclin E1 expression and perturbs intestinal carcinogenesis. Mol Cancer Res 13: 1185-1196, 2015.

41. Ku DH, Wen SC, Engelhard A, Nicolaides NC, Lipson KE, Marino TA and Calabretta B: c-myb transactivates cdc2 expression via Myb binding sites in the 5'-flanking region of the human cdc2 gene. J Biol Chem 268: 2255-2259, 1993. 
42. Nakata Y, Shetzline S, Sakashita C, Kalota A, Rallapalli R, Rudnick SI, Zhang Y, Emerson SG and Gewirtz AM: c-Myb contributes to G2/M cell cycle transition in human hematopoietic cells by direct regulation of cyclin B1 expression. Mol Cell Biol 27: 2048-2058, 2007.

43. Liu F, Lei W, O'Rourke JP and Ness SA: Oncogenic mutations cause dramatic, qualitative changes in the transcriptional activity of c-Myb. Oncogene 25: 795-805, 2006.

44. Gravina GL, Mancini A,MaramponF, Colapietro A,Delle Monache S, Sferra R, Vitale F, Richardson PJ, Patient L, Burbidge S, et al: The brain-penetrating CXCR4 antagonist, PRX177561, increases the antitumor effects of bevacizumab and sunitinib in preclinical models of human glioblastoma. J Hematol Oncol 10: 5, 2017.

45. Knopfová L, Beneš P, Pekarč́ková L, Hermanová M, Masařík M, Pernicová Z, Souček K and Smarda J: c-Myb regulates matrix metalloproteinases 1/9, and cathepsin D: Implications for matrix-dependent breast cancer cell invasion and metastasis. Mol Cancer 11: 15, 2012.

46. Chen RX, Xia YH, Xue TC and Ye SL: Transcription factor c-Myb promotes the invasion of hepatocellular carcinoma cells via increasing osteopontin expression. J Exp Clin Cancer Res 29: $172,2010$.
47. Oka N, Soeda A, Inagaki A, Onodera M, Maruyama H, Hara A, Kunisada T, Mori H and Iwama T: VEGF promotes tumorigenesis and angiogenesis of human glioblastoma stem cells. Biochem Biophys Res Commun 360: 553-559, 2007.

48. Sluiter N, de Cuba E, Kwakman R, Kazemier G, Meijer G and Te Velde EA: Adhesion molecules in peritoneal dissemination: Function, prognostic relevance and therapeutic options. Clin Exp Metastasis 33: 401-416, 2016

49. Lauer-Fields JL, Whitehead JK, Li S, Hammer RP, Brew K and Fields GB: Selective modulation of matrix metalloproteinase 9 (MMP-9) functions via exosite inhibition. J Biol Chem 283: 20087-20095, 2008.

50. Sala A: c-MYB and TGF $\beta$ : EMT's dynamic duo in breast cancer. Cell Cycle 11: 17, 2012.

(1)(9) This work is licensed under a Creative Commons Attribution-NonCommercial-NoDerivatives 4.0 International (CC BY-NC-ND 4.0) License. 